\title{
RELATIONSHIP BETWEEN RESPONSE RATE AND REINFORCEMENT FREQUENCY IN \\ VARIABLE-INTERVAL SCHEDULES: III. THE EFFECT OF d-AMPHETAMINE
}

\author{
C. M. Bradshaw, H. V. Ruddle, and E. Szabadi
}

\author{
UNIVERSITY OF MANCHESTER
}

\begin{abstract}
Four rats were exponsed to variable-interval schedules specifying a range of different reinforcement frequencies. The effects of two doses of $d$-amphetamine $(1.6$ and $3.2 \mu \mathrm{mol} / \mathrm{kg}$ ) upon performance maintained under each schedule were examined. In the case of each rat, the response rates observed under control conditions (no injection or injection of the vehicle alone) were increasing, negatively accelerated functions of reinforcement frequency, the data conforming closely to Herrnstein's (1970) equation. In each rat, $d$-amphetamine $(3.2 \mu \mathrm{mol} / \mathrm{kg})$ significantly reduced the value of the constant $R_{\max }$, which expresses the theoretical maximum response rate. In each rat, the value of $K_{H}$, which expresses the reinforcement frequency needed to obtain the half-maximal response rate, was also reduced, although this only achieved statistical significance in the case of one rat. When the proportional change in response rate in the presence of the drug was plotted against the response rate under control conditions on double logarithmic co-ordinates, linear functions of negative slope were obtained; in each rat the slope was steeper and the value of the control response rate at which $d$-amphetamine exerted no effect was lower in the case of the higher dose $(3.2 \mu \mathrm{mol} / \mathrm{kg})$ than in the case of the lower dose $(1.6 \mu \mathrm{mol} / \mathrm{kg})$.

Key words: Herrnstein's equation, response rate, reinforcement frequency, $d$-amphetamine, rate dependency, variable interval, lever press, rats
\end{abstract}

Herrnstein (1970) proposed an equation of the following form to describe the relationship between response rate $(R)$ and reinforcement frequency $(r)$ in variable-interval schedules of reinforcement:

$$
R=R_{\max } \cdot r /\left(K_{H}+r\right)
$$

where $R_{\max }$ and $K_{H}$ are constants expressing the theoretical maximum response rate that can be generated in a variable-interval schedule, and the reinforcement frequency needed to obtain the half-maximal response rate respectively (Herrnstein, 1970, 1974; see also Bradshaw, Szabadi, \& Bevan, 1978b). There is abundant evidence that the behavior of a variety of species in variable-interval schedules is accurately described by this equation (see de Villiers, 1977). There have been no

This work was supported by the North Western Regional Health Authority of Great Britain. We are grateful to Margaret Gill for skilled technical assistance. Address for correspondence and reprints: Department of Psychiatry, University of Manchester, Stopford Building, Oxford Road, Manchester M13 9PT, United Kingdom. previous reports of the effects of drugs upon the relationship described by Equation 1. We report here some observations on the effect of $d$-amphetamine upon this relationship.

The effects of amphetamines upon operant performance have been extensively studied. Dews (1958) observed that $d$-amphetamine suppressed the high response rates maintained under fixed-ratio schedules, but elevated the lower response rates maintained under fixedinterval schedules. He proposed that the effects of amphetamines on operant performance depend upon the rate of responding maintained under control conditions. The results of subsequent studies have generally been in accord with this "rate-dependency hypothesis" of the effects of amphetamines (for review, see Dews \& DeWeese, 1977; Dews \& Wenger, 1977; Sanger \& Blackman, 1976). In order to examine this hypothesis, it is necessary to generate a wide range of response rates. Although numerous procedures have been devised to achieve this end, few studies have employed systematic manipulations of schedule parameters (for an example of the use of fixed-interval schedules in this way, see Dews, 1962). 
Variable-interval schedules may have several advantages for studying the behavioral effects of amphetamines. First, the relationship between reinforcement frequency and response rate defined by Equation 1 suggests that a wide range of response rates may be generated by manipulating reinforcement frequency. Second, variable-interval schedules have the property of maintaining relatively uniform response rates unsullied by long pauses $(\mathrm{Ca}-$ tania \& Reynolds, 1968; Ferster \& Skinner, 1957); thus, the effects of amphetamines upon variable-interval performance are unlikely to be contaminated by the effects of averaging dissimilar local response rates (for discussion, see Branch \& Gollub, 1974).

Although the effects of amphetamines have not previously been examined in the context of Equation 1, the rate-dependency hypothesis suggests certain predictions concerning the effects of these drugs on the values of the two constants, $R_{\max }$ and $K_{H}$. It might be expected that the suppression of high response rates by amphetamines would be reflected in a reduction in the maximum response rate $\left(\boldsymbol{R}_{\text {max }}\right)$. On the other hand, the ability of amphetamines to increase low rates of responding might result in the half-maximal response rate being attained with a lower reinforcement frequency in the presence of amphetamines than under control conditions; thus, it might be expected that amphetamines would cause a reduction in the value of $K_{H}$.

\section{METHOD}

\section{Subjects}

Four experimentally naive female albino Wistar rats (R66, R67, R68, and R69), bred in our laboratory and aged about 4.5 months at the start of training were used. The rats were housed individually under a constant cycle of 12-hr light and 12-hr darkness, and were maintained at approximately $80 \%$ of their initial free-feeding body weights throughout the experiment. Tap water was freely available in the home cages.

\section{Apparatus}

The rats were trained in a standard operant conditioning chamber (Campden Instruments Ltd., Model 410 ) measuring $20 \mathrm{~cm}$ high by 23 $\mathrm{cm}$ wide by $22.5 \mathrm{~cm}$ long. The front wall contained a recess into which a motor-operated dipper could deliver $.05 \mathrm{ml}$ of liquid reinforcer. The dipper was normally out of reach of the animal; reinforcer delivery consisted of raising the dipper into the recess for $5 \mathrm{sec}$. An aperture was situated $5.0 \mathrm{~cm}$ above and $2.5 \mathrm{~cm}$ to the right of the recess; a motor-driven retractable lever could be inserted into the chamber through this aperture. The lever could be depressed by a force of approximately $.1 \mathrm{~N}$. The chamber was fitted with a 2.8-W houselight in the center of the roof, and was enclosed in a sound-attenuating chest; masking noise was provided by a rotary fan. Conventional electromechanical programming and recording apparatus was situated in an adjoining room.

\section{Procedure}

After acclimatization to the food-deprivation regime, the rats were trained to press the lever by the method of successive approximations. After three sessions' exposure to a continuous reinforcement schedule, they were subjected to a series of variable-interval schedules as described below. Experimental sessions took place daily, at the same time each day. Each session was initiated by insertion of the lever into the chamber, and was terminated by withdrawal of the lever after 49 reinforcements had been delivered or after $60 \mathrm{~min}$, whichever occurred sooner.

Constant-probability variable-interval schedules were used throughout the experiment (Catania \& Reynolds, 1968); there were 25 intervals in each schedule. The reinforcer, Fussell's sweetened condensed milk diluted 1:4 in tap water, was prepared daily before each experimental session.

The schedules of reinforcement used and the number of sessions' exposure to each schedule are shown in Table 1. The animals were exposed to each schedule for at least 28 successive sessions before drug treatment was started, the injection regimen generally being instituted on the first Monday following the 28 th session. Injections were given intraperitoneally using a 25 -gauge needle $10 \mathrm{~min}$ before the start of the experimental session. The volume injected was always $2.5 \mathrm{ml}$ per $\mathrm{kg}$ body weight, the vehicle being sterile distilled water. Injections of vehicle alone were given on Mondays and Thursdays, and injections of the drug solution on Tuesdays and Fridays; no injections were given on Wednesdays, Satur- 


\section{Table 1}

Variable-Interval schedules used during the experiment, in the order of their presentation.

\begin{tabular}{cc}
\hline $\begin{array}{c}\text { Variable-Interval schedule } \\
\text { (in seconds) }\end{array}$ & $\begin{array}{c}\text { Number of } \\
\text { sessions }\end{array}$ \\
\hline VI 10.6 & 57 \\
VI 30.0 & 62 \\
VI 53.0 & 56 \\
VI 109.0 & 55 \\
VI 200.0 & 56 \\
VI 360.0 & 82 \\
VI 26.7 & $54^{*}$ \\
\hline
\end{tabular}

* R67 died before the completion of training under this schedule.

days, or Sundays. The injection regimen continued for four weeks; during the first two weeks the dose of $d$-amphetamine was $1.6 \mu \mathrm{mol}$ per kg body weight, and during the second two weeks the dose was $3.2 \mu \mathrm{mol}$ per $\mathrm{kg}$ body weight. The doses were administered as .3 $\mathrm{mg} / \mathrm{kg}$ and $.6 \mathrm{mg} / \mathrm{kg} d$-amphetamine sulphate.

\section{RESUlTS}

The data obtained from each rat were analyzed separately. Only the data obtained during the "terminal sessions" of exposure to each schedule (i.e., the 26 sessions after the start of the injection regimen) were included in the analysis. Mean response rates $( \pm$ standard error of the mean) were calculated for the four sessions in which $d$-amphetamine $1.6 \mu \mathrm{mol} / \mathrm{kg}$ was administered, the four sessions in which $d$-amphetamine $3.2 \mu \mathrm{mol} / \mathrm{kg}$ was administered, the eight sessions in which the vehicle alone was administered, and the 10 sessions in which no injection was given. Statistical analysis of the data obtained from each rat under each reinforcement schedule did not reveal any significant differences between the response rates observed in the "vehicle alone" sessions and the "no injection" sessions $(t$ test: $p>.1)$, and therefore the data obtained from both types of "control" session were pooled $(n=18)$.

The response rates and delivered reinforcement frequencies obtained in the presence of each schedule under each of the three treatment conditions are shown in Table 2. The high response rates maintained by the schedules affording high frequencies of reinforcement were reduced following injections of $d$-amphetamine, particularly at the higher dose level $(3.2 \mu \mathrm{mol} / \mathrm{kg})$. In contrast, the lower response rates maintained by the schedules which afforded low reinforcement frequencies were either unaffected or were elevated by $d$-amphetamine. This observation is illustrated in Figure 1, which shows sample cumulative records obtained from one rat, R67.

In order to examine the effect of $d$-amphetamine upon the values of $R_{\max }$ and $K_{H}$ (cf. Equation 1), best-fit hyperbolic functions (i.e., functions having the form defined by Equation 1) were fitted to the data obtained from each rat under each of the three treatment conditions using the method of Wilkinson (1961). The curves derived for the control data and the $3.2 \mu \mathrm{mol} / \mathrm{kg}$ data are illustrated in Figure 2 , and the estimated values of $R_{\max }$ and $K_{H}$ ( \pm standard error of the estimate) derived for each treatment condition are shown in Table 3. Also shown in Table 3 are the indices of determination, $p^{2}$, derived for each set of data. (The index of determination expresses the proportion of the variance in the $y$-values which can be accounted for in terms of $x$ in a curvilinear function (Lewis, 1960; see also Bradshaw, Szabadi, \& Bevan, 1976).) The effect of $d$-amphetamine upon $R_{\max }$ was generally to reduce the value of this constant. The lower dose $(1.6 \mu \mathrm{mol} / \mathrm{kg})$ produced a statistically significant reduction only in the case of one rat, R67 (normal distribution, $p<.05$ ); however the higher dose $(3.2 \mu \mathrm{mol} / \mathrm{kg})$ produced a significant reduction in the case of three animals (R67: $p<.00001$; R68: $p<.001$; R69: $p<.001)$. The effect of the drug upon the value of $K_{H}$ was more variable: in each rat the value obtained with $3.2 \mu \mathrm{mol} / \mathrm{kg}$ was lower than that obtained under control conditions, but this difference achieved statistical significance only in the case of $\mathrm{R} 67$ ( $p<$ $.05)$. The values of $p^{2}$ ranged between .67 and .98 ; in general the values of $p^{2}$ obtained under the drug treatment conditions were lower than those obtained under control conditions.

Figure 3 shows the response rates observed in the presence of the two doses of $d$-amphetamine, expressed as percentages of the control rates, plotted against control response rates on double logarithmic coordinates. Best fit linear functions were fitted to the data obtained from each rat under each dose of $d$-amphetamine, using the method of least squares. In the case of each rat, the fitted lines had negative slopes, the slope obtained with the higher dose (3.2 
Table 2

Data Obtained from each Subject during the Terminal Sessions under each Schedule*

\begin{tabular}{|c|c|c|c|c|}
\hline Subject & $\begin{array}{l}\text { Variable- } \\
\text { interval } \\
\text { schedule } \\
(\mathrm{sec})\end{array}$ & Treatment & $\begin{array}{l}\text { Obtained } \\
\text { reinforcement } \\
\text { frequency } \\
(\text { reinf/hr) }\end{array}$ & $\begin{array}{l}\text { Response } \\
\text { rate } \\
\text { (resp/min) } \\
\pm \text { s.e.m. }\end{array}$ \\
\hline \multirow[t]{7}{*}{ R 66} & VI 10.6 & $\begin{array}{l}\text { control } \uparrow \\
d \text {-amphetamine } 1.6 \mu \mathrm{mol} / \mathrm{kg} \\
d \text {-amphetamine } 3.2 \mu \mathrm{mol} / \mathrm{kg}\end{array}$ & $\begin{array}{l}312.2 \\
331.1 \\
311.2\end{array}$ & $\begin{array}{l}79.4( \pm 2.2) \\
90.3( \pm 6.4) \\
60.2( \pm \quad .8)\end{array}$ \\
\hline & VI 30.0 & $\begin{array}{l}\text { control } \\
d \text {-amphetamine } 1.6 \mu \mathrm{mol} / \mathrm{kg} \\
d \text {-amphetamine } 3.2 \mu \mathrm{mol} / \mathrm{kg}\end{array}$ & $\begin{array}{r}113.0 \\
114.4 \\
97.9\end{array}$ & $\begin{array}{r}90.1( \pm 2.1) \\
104.4( \pm 1.6) \\
53.1( \pm 21.1)\end{array}$ \\
\hline & VI 53.0 & $\begin{array}{l}\text { control } \\
d \text {-amphetamine } 1.6 \mu \mathrm{mol} / \mathrm{kg} \\
d \text {-amphetamine } 3.2 \mu \mathrm{mol} / \mathrm{kg}\end{array}$ & $\begin{array}{l}64.5 \\
63.3 \\
62.7\end{array}$ & $\begin{array}{l}56.0( \pm 4.0) \\
33.1( \pm 12.3) \\
29.4( \pm 5.3)\end{array}$ \\
\hline & VI 109.0 & $\begin{array}{l}\text { control } \\
d \text {-amphetamine } 1.6 \mu \mathrm{mol} / \mathrm{kg} \\
d \text {-amphetamine } 3.2 \mu \mathrm{mol} / \mathrm{kg}\end{array}$ & $\begin{array}{l}29.6 \\
29.6 \\
30.4\end{array}$ & $\begin{array}{l}17.8( \pm 1.1) \\
18.7( \pm 2.1) \\
18.7( \pm 3.2)\end{array}$ \\
\hline & VI 200.0 & $\begin{array}{l}\text { control } \\
d \text {-amphetamine } 1.6 \mu \mathrm{mol} / \mathrm{kg} \\
d \text {-amphetamine } 3.2 \mu \mathrm{mol} / \mathrm{kg}\end{array}$ & $\begin{array}{l}16.2 \\
16.6 \\
17.4\end{array}$ & $\begin{array}{r}7.0( \pm .3) \\
10.0( \pm 1.9) \\
16.2( \pm 2.9)\end{array}$ \\
\hline & VI 360.0 & $\begin{array}{l}\text { control } \\
d \text {-amphetamine } 1.6 \mu \mathrm{mol} / \mathrm{kg} \\
d \text {-amphetamine } 3.2 \mu \mathrm{mol} / \mathrm{kg}\end{array}$ & $\begin{array}{l}8.5 \\
8.3 \\
8.8\end{array}$ & $\begin{array}{r}6.1( \pm \quad .4) \\
9.6( \pm 4.1) \\
12.3( \pm 4.6)\end{array}$ \\
\hline & VI 26.7 & $\begin{array}{l}\text { control } \\
d \text {-amphetamine } 1.6 \mu \mathrm{mol} / \mathrm{kg} \\
d \text {-amphetamine } 3.2 \mu \mathrm{mol} / \mathrm{kg}\end{array}$ & $\begin{array}{l}130.5 \\
133.5 \\
126.8\end{array}$ & $\begin{array}{l}75.8( \pm 5.5) \\
76.3( \pm 13.1) \\
41.6( \pm 6.0)\end{array}$ \\
\hline \multirow[t]{6}{*}{ R 67} & VI 10.6 & $\begin{array}{l}\text { control } \\
d \text {-amphetamine } 1.6 \mu \mathrm{mol} / \mathrm{kg} \\
d \text {-amphetamine } 3.2 \mu \mathrm{mol} / \mathrm{kg}\end{array}$ & $\begin{array}{l}297.5 \\
266.9 \\
293.4\end{array}$ & $\begin{array}{l}69.7( \pm 1.6) \\
47.9( \pm 6.5) \\
50.4( \pm 5.9)\end{array}$ \\
\hline & VI 30.0 & $\begin{array}{l}\text { control } \\
d \text {-amphetamine } 1.6 \mu \mathrm{mol} / \mathrm{kg} \\
d \text {-amphetamine } 3.2 \mu \mathrm{mol} / \mathrm{kg}\end{array}$ & $\begin{array}{l}112.5 \\
115.1 \\
105.4\end{array}$ & $\begin{array}{l}65.4( \pm \quad .9) \\
68.6( \pm 2.2) \\
33.0( \pm 5.6)\end{array}$ \\
\hline & VI 53.0 & $\begin{array}{l}\text { control } \\
d \text {-amphetamine } 1.6 \mu \mathrm{mol} / \mathrm{kg} \\
d \text {-amphetamine } 3.2 \mu \mathrm{mol} / \mathrm{kg}\end{array}$ & $\begin{array}{l}66.4 \\
64.7 \\
63.6\end{array}$ & $\begin{array}{l}54.4( \pm 1.2) \\
39.8( \pm 4.1) \\
26.2( \pm 3.2)\end{array}$ \\
\hline & VI 109.0 & $\begin{array}{l}\text { control } \\
d \text {-amphetamine } 1.6 \mu \mathrm{mol} / \mathrm{kg} \\
d \text {-amphetamine } 3.2 \mu \mathrm{mol} / \mathrm{kg}\end{array}$ & $\begin{array}{l}31.5 \\
32.6 \\
31.0\end{array}$ & $\begin{array}{l}38.2( \pm 1.6) \\
38.8( \pm 3.1) \\
27.0( \pm 4.2)\end{array}$ \\
\hline & VI 200.0 & $\begin{array}{l}\text { control } \\
d \text {-amphetamine } 1.6 \mu \mathrm{mol} / \mathrm{kg} \\
d \text {-amphetamine } 3.2 \mu \mathrm{mol} / \mathrm{kg}\end{array}$ & $\begin{array}{l}16.9 \\
17.1 \\
17.9\end{array}$ & $\begin{array}{l}23.3( \pm 1.3) \\
32.2( \pm .8) \\
25.6( \pm 2.2)\end{array}$ \\
\hline & VI 360.0 & $\begin{array}{l}\text { control } \\
d \text {-amphetamine } 1.6 \mu \mathrm{mol} / \mathrm{kg} \\
d \text {-amphetamine } 3.2 \mu \mathrm{mol} / \mathrm{kg}\end{array}$ & $\begin{array}{r}9.4 \\
8.7 \\
11.1\end{array}$ & $\begin{array}{l}10.1( \pm .5) \\
18.3( \pm 2.9) \\
23.2( \pm 3.3)\end{array}$ \\
\hline R 68 & VI 10.6 & $\begin{array}{l}\text { control } \\
d \text {-amphetamine } 1.6 \mu \mathrm{mol} / \mathrm{kg} \\
d \text {-amphetamine } 3.2 \mu \mathrm{mol} / \mathrm{kg}\end{array}$ & $\begin{array}{l}307.4 \\
301.0 \\
278.8\end{array}$ & $\begin{array}{l}62.6( \pm 1.5) \\
52.2( \pm 4.3) \\
33.3( \pm .8)\end{array}$ \\
\hline
\end{tabular}

$\mu \mathrm{mol} / \mathrm{kg}$ ) having a greater negative value than that obtained with the lower dose (1.6 $\mu \mathrm{mol} / \mathrm{kg})$. The correlation coefficients ranged between -.586 and -.952 , negative values in excess of -.75 being obtained in seven out of the eight cases. The horizontal broken line in each graph indicates the ordinate value of $2.0(\log 100)$; the point of intersection of the fitted line with the horizontal broken line corresponds to the value of the control response rate at which the drug has no effect, either suppressant or facilitatory. In each rat, this value was lower in the case of $1.6 \mu \mathrm{mol} / \mathrm{kg}$ than in the case of $3.2 \mu \mathrm{mol} / \mathrm{kg}$. 
Table 2 continued

\begin{tabular}{|c|c|c|c|c|}
\hline Subject & $\begin{array}{l}\text { Variable- } \\
\text { interval } \\
\text { schedule } \\
\quad(\mathrm{sec})\end{array}$ & Treatment & $\begin{array}{l}\text { Obtained } \\
\text { reinforcement } \\
\text { frequency } \\
(\text { reinf/hr) }\end{array}$ & $\begin{array}{c}\text { Response } \\
\text { rate } \\
\text { (resp/min) } \\
\text { 土s.e.m. }\end{array}$ \\
\hline & VI 30.0 & $\begin{array}{l}\text { control } \\
d \text {-amphetamine } 1.6 \mu \mathrm{mol} / \mathrm{kg} \\
d \text {-amphetamine } 3.2 \mu \mathrm{mol} / \mathrm{kg}\end{array}$ & $\begin{array}{l}111.5 \\
111.6 \\
106.2\end{array}$ & $\begin{array}{l}67.5( \pm 1.6) \\
72.6( \pm \quad .7) \\
35.1( \pm 3.3)\end{array}$ \\
\hline & VI 53.0 & $\begin{array}{l}\text { control } \\
d \text {-amphetamine } 1.6 \mu \mathrm{mol} / \mathrm{kg} \\
d \text {-amphetamine } 3.2 \mu \mathrm{mol} / \mathrm{kg}\end{array}$ & $\begin{array}{l}65.2 \\
64.9 \\
63.9\end{array}$ & $\begin{array}{l}48.6( \pm 1.4) \\
40.9( \pm 3.4) \\
24.7( \pm 1.2)\end{array}$ \\
\hline & VI 109.0 & $\begin{array}{l}\text { control } \\
d \text {-amphetamine } 1.6 \mu \mathrm{mol} / \mathrm{kg} \\
d \text {-amphetamine } 3.2 \mu \mathrm{mol} / \mathrm{kg}\end{array}$ & $\begin{array}{l}31.6 \\
30.7 \\
31.8\end{array}$ & $\begin{array}{l}26.5( \pm \quad .6) \\
27.8( \pm 3.0) \\
25.1( \pm 1.7)\end{array}$ \\
\hline & VI 200.0 & $\begin{array}{l}\text { control } \\
d \text {-amphetamine } 1.6 \mu \mathrm{mol} / \mathrm{kg} \\
d \text {-amphetamine } 3.2 \mu \mathrm{mol} / \mathrm{kg}\end{array}$ & $\begin{array}{l}17.2 \\
17.7 \\
16.7\end{array}$ & $\begin{array}{l}18.5( \pm \quad .4) \\
21.8( \pm 2.1) \\
14.4( \pm 1.7)\end{array}$ \\
\hline & VI 360.0 & $\begin{array}{l}\text { control } \\
d \text {-amphetamine } 1.6 \mu \mathrm{mol} / \mathrm{kg} \\
d \text {-amphetamine } 3.2 \mu \mathrm{mol} / \mathrm{kg}\end{array}$ & $\begin{array}{l}9.0 \\
8.3 \\
8.8\end{array}$ & $\begin{array}{r}7.9( \pm \quad .4) \\
13.3( \pm \quad .9) \\
13.0( \pm \quad .7)\end{array}$ \\
\hline & VI 26.7 & $\begin{array}{l}\text { control } \\
d \text {-amphetamine } 1.6 \mu \mathrm{mol} / \mathrm{kg} \\
d \text {-amphetamine } 3.2 \mu \mathrm{mol} / \mathrm{kg}\end{array}$ & $\begin{array}{l}128.2 \\
130.3 \\
126.2\end{array}$ & $\begin{array}{l}56.7( \pm 3.5) \\
53.2( \pm 8.9) \\
34.3( \pm 11.4)\end{array}$ \\
\hline \multirow[t]{7}{*}{ R 69} & VI 10.6 & $\begin{array}{l}\text { control } \\
d \text {-amphetamine } 1.6 \mu \mathrm{mol} / \mathrm{kg} \\
d \text {-amphetamine } 3.2 \mu \mathrm{mol} / \mathrm{kg}\end{array}$ & $\begin{array}{l}299.4 \\
294.9 \\
280.3\end{array}$ & $\begin{array}{l}53.3( \pm \quad .8) \\
50.5( \pm 6.5) \\
25.6( \pm 4.1)\end{array}$ \\
\hline & VI 30.0 & $\begin{array}{l}\text { control } \\
d \text {-amphetamine } 1.6 \mu \mathrm{mol} / \mathrm{kg} \\
d \text {-amphetamine } 3.2 \mu \mathrm{mol} / \mathrm{kg}\end{array}$ & $\begin{array}{l}111.0 \\
103.9 \\
108.3\end{array}$ & $\begin{array}{l}62.5( \pm 2.1) \\
66.2( \pm 6.3) \\
27.4( \pm 3.3)\end{array}$ \\
\hline & VI 53.0 & $\begin{array}{l}\text { control } \\
d \text {-amphetamine } 1.6 \mu \mathrm{mol} / \mathrm{kg} \\
d \text {-amphetamine } 3.2 \mu \mathrm{mol} / \mathrm{kg}\end{array}$ & $\begin{array}{l}64.0 \\
66.0 \\
63.8\end{array}$ & $\begin{array}{l}43.4( \pm 1.6) \\
34.1( \pm 4.8) \\
14.0( \pm \quad .4)\end{array}$ \\
\hline & VI 109.0 & $\begin{array}{l}\text { control } \\
d \text {-amphetamine } 1.6 \mu \mathrm{mol} / \mathrm{kg} \\
d \text {-amphetamine } 3.2 \mu \mathrm{mol} / \mathrm{kg}\end{array}$ & $\begin{array}{l}30.9 \\
31.0 \\
30.7\end{array}$ & $\begin{array}{l}25.0( \pm \quad .9) \\
24.9( \pm 1.4) \\
14.3( \pm \quad .6)\end{array}$ \\
\hline & VI 200.0 & $\begin{array}{l}\text { control } \\
d \text {-amphetamine } 1.6 \mu \mathrm{mol} / \mathrm{kg} \\
d \text {-amphetamine } 3.2 \mu \mathrm{mol} / \mathrm{kg}\end{array}$ & $\begin{array}{l}16.9 \\
17.4 \\
17.4\end{array}$ & $\begin{array}{l}19.6( \pm \quad .9) \\
17.7( \pm 1.2) \\
14.9( \pm 1.1)\end{array}$ \\
\hline & VI 360.0 & $\begin{array}{l}\text { control } \\
d \text {-amphetamine } 1.6 \mu \mathrm{mol} / \mathrm{kg} \\
d \text {-amphetamine } 3.2 \mu \mathrm{mol} / \mathrm{kg}\end{array}$ & $\begin{array}{l}8.2 \\
8.9 \\
8.4\end{array}$ & 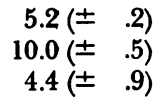 \\
\hline & VI 26.7 & $\begin{array}{l}\text { control } \\
d \text {-amphetamine } 1.6 \mu \mathrm{mol} / \mathrm{kg} \\
d \text {-amphetamine } 3.2 \mu \mathrm{mol} / \mathrm{kg}\end{array}$ & $\begin{array}{l}125.1 \\
121.7 \\
117.3\end{array}$ & $\begin{array}{l}44.0( \pm 3.2) \\
30.6( \pm 5.0) \\
13.0( \pm 1.1)\end{array}$ \\
\hline
\end{tabular}

" "Terminal" sessions followed at least 28 preliminary sessions of training under a schedule.

$f$ "Control" data are the pooled data from sessions in which no injection was given and those in which injections of the vehicle alone (distilled water) were given (see text).

\section{DISCUSSION}

The results obtained from each rat under control conditions (i.e., in the absence of $d$ amphetamine) conformed closely to Herrnstein's equation, the proportion of the data variance accounted for being between 87 and $98 \%$. This finding is in agreement with pre- vious observations of the behavior of rats under variable-interval schedules [Bradshaw 1977, Bradshaw et al., 1978b; de Villiers (data reported in de Villiers \& Herrnstein, 1976)]. (The trend, seen in three of the rats, for response rates maintained under variable-interval 10.6 to be somewhat lower than those maintained under variable-interval 30.0 (see 


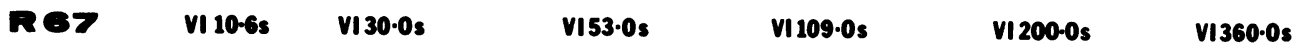
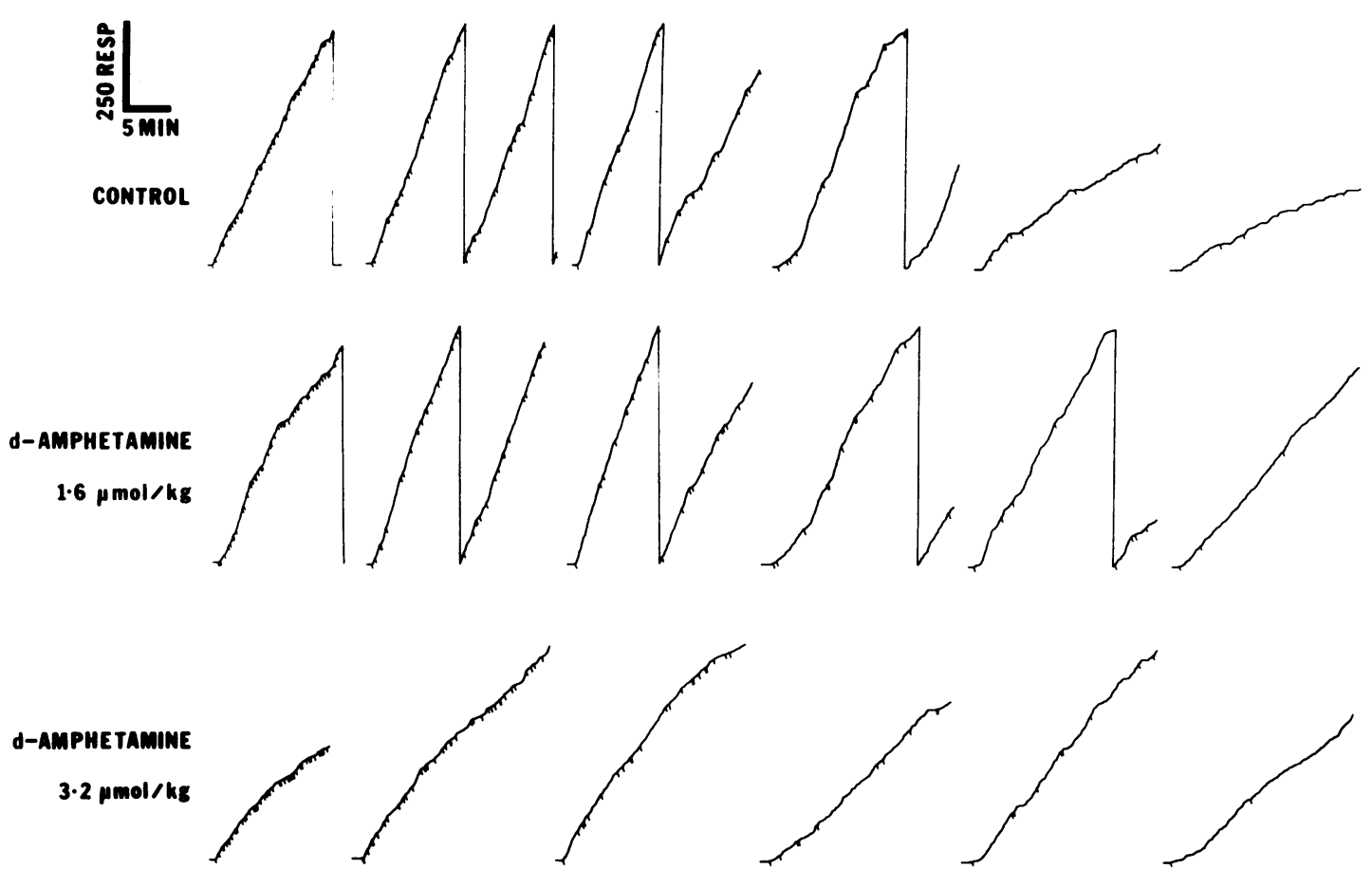

Fig. 1. Sample cumulative records obtained from one rat ( $R$ 67). Records were taken from terminal sessions under each schedule. Top row: control sessions; middle row: sessions in which $d$-amphetamine $1.6 \mu$ mol/kg was injected intraperitoneally; bottom row: sessions in which $d$-amphetamine $3.2 \mu \mathrm{mol} / \mathrm{kg}$ was given. Note that the drug suppressed response rates under schedules specifying high reinforcement frequencies, and elevated response rates under schedules specifying low reinforcement frequencies.

\section{Table 3}

Values of the Two Constants in Equation 1 and Goodness of Fit of the Hyperbolic Functions

\begin{tabular}{|c|c|c|c|c|}
\hline Subject & Treatment & $\begin{array}{l}\text { Value of } \\
K_{H} \\
\text { (reinf/hr) }\end{array}$ & $\begin{array}{l} \pm \text { s.e.est }) \\
\qquad \begin{array}{l}R_{\max } \\
(\text { resp } / \min )\end{array}\end{array}$ & $p^{2}$ \\
\hline R 66 & $\begin{array}{l}\text { control } \downarrow \\
d \text {-amphetamine } 1.6 \mu \mathrm{mol} / \mathrm{kg} \\
d \text {-amphetamine } 3.2 \mu \mathrm{mol} / \mathrm{kg}\end{array}$ & $\begin{array}{r}79.1( \pm 53.7) \\
106.7( \pm 89.9) \\
71.6( \pm 26.5)\end{array}$ & $\begin{array}{r}114.3( \pm 27.1) \\
134.2( \pm 37.6) \\
76.5( \pm 11.1)\end{array}$ & $\begin{array}{l}.87 \\
.81 \\
.93\end{array}$ \\
\hline R 67 & $\begin{array}{l}\text { control } f \\
d \text {-amphetamine } 1.6 \mu \mathrm{mol} / \mathrm{kg} \\
d \text {-amphetamine } 3.2 \mu \mathrm{mol} / \mathrm{kg}\end{array}$ & $\begin{array}{l}39.7( \pm 8.0) \\
17.1( \pm 10.4)^{*} \\
16.2( \pm 8.5)^{*}\end{array}$ & $\begin{array}{l}83.3( \pm 5.5) \\
60.1( \pm 11.3)^{*} \\
44.4( \pm 6.6) * * *\end{array}$ & $\begin{array}{l}.98 \\
.71 \\
.67\end{array}$ \\
\hline R 68 & $\begin{array}{l}\text { control } \nmid \\
d \text {-amphetamine } 1.6 \mu \mathrm{mol} / \mathrm{kg} \\
d \text {-amphetamine } 3.2 \mu \mathrm{mol} / \mathrm{kg}\end{array}$ & $\begin{array}{l}49.7( \pm 19.6) \\
34.9( \pm 22.1) \\
19.3( \pm 6.2)\end{array}$ & $\begin{array}{l}81.0( \pm 11.8) \\
69.7( \pm 18.0) \\
36.9( \pm 3.3)^{* *}\end{array}$ & $\begin{array}{l}.93 \\
.78 \\
.90\end{array}$ \\
\hline R 69 & $\begin{array}{l}\text { control } \nmid \\
d \text {-amphetamine } 1.6 \mu \mathrm{mol} / \mathrm{kg} \\
d \text {-amphetamine } 3.2 \mu \mathrm{mol} / \mathrm{kg}\end{array}$ & $\begin{array}{l}42.3( \pm 19.7) \\
42.5( \pm 27.7) \\
29.7( \pm 16.8)\end{array}$ & $\begin{array}{l}69.6( \pm 11.8) \\
67.0( \pm 18.3) \\
29.0( \pm 5.2)^{* *}\end{array}$ & $\begin{array}{l}.90 \\
.79 \\
.79\end{array}$ \\
\hline
\end{tabular}

tThe data from sessions in which injections of the vehicle alone (distilled water) were given were pooled with the data in which no injection was given (see text).

Significance of difference from value of constant obtained under control conditions (normal distribution): $* p<.05, * * p<.001, * * * p<.00001$. 

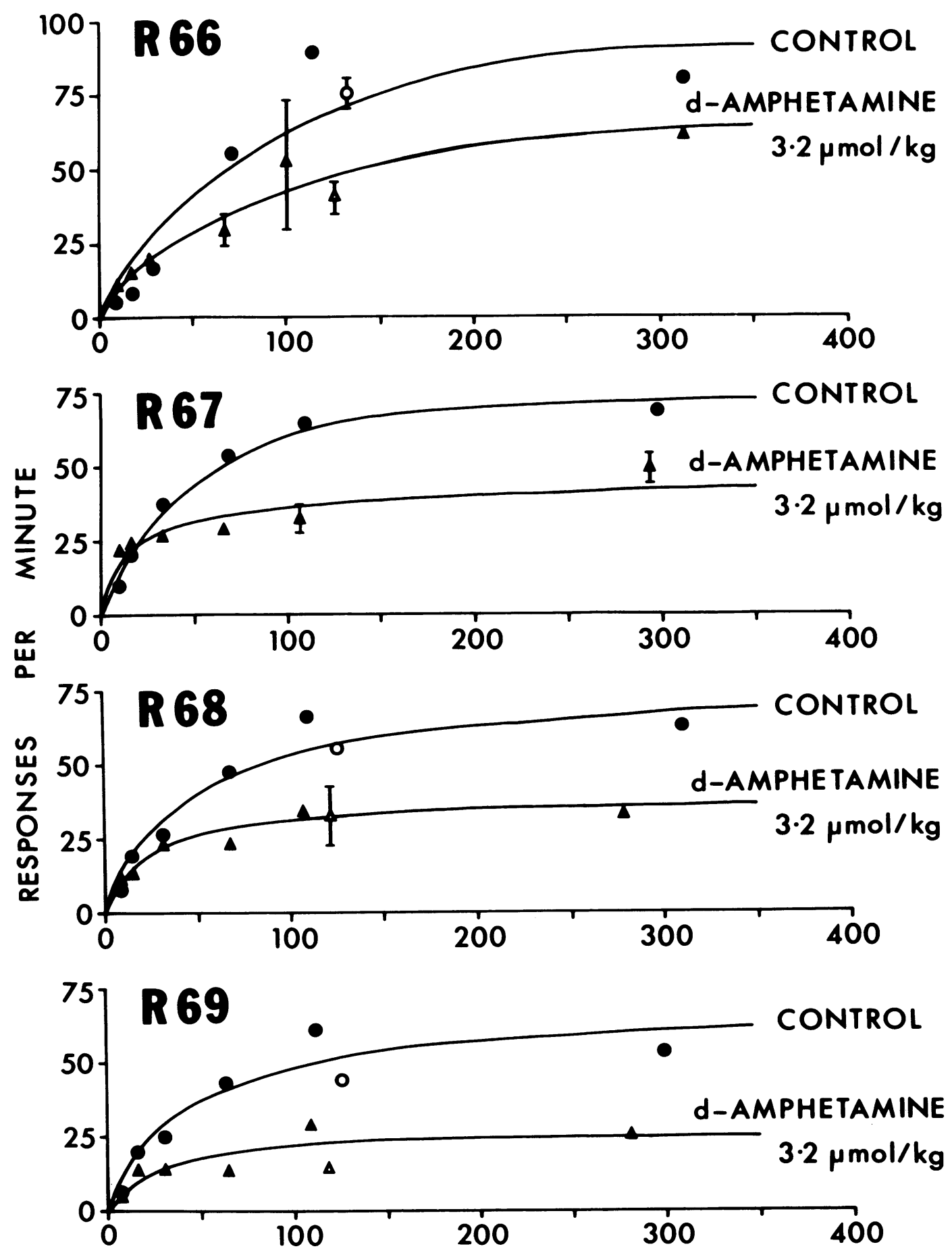

DELIVERED REINFORCEMENTS PER HOUR

Fig. 2. Relationship between response rate and reinforcement frequency for each of the four rats. Points show mean response rates for terminal sessions under each schedule; vertical bars indicate \pm s.e. mean, where this was greater than \pm 5 responses per minute. Circles: control sessions; triangles: sessions in which $3.2 \mu \mathrm{mol} / \mathrm{kg} d$ amphetamine was injected intraperitoneally. Unfilled symbols indicate data obtained under VI 26.7-sec (last condition of experiment). Curves are best-fit rectangular hyperbolae, fitted by nonlinear regression analysis. 


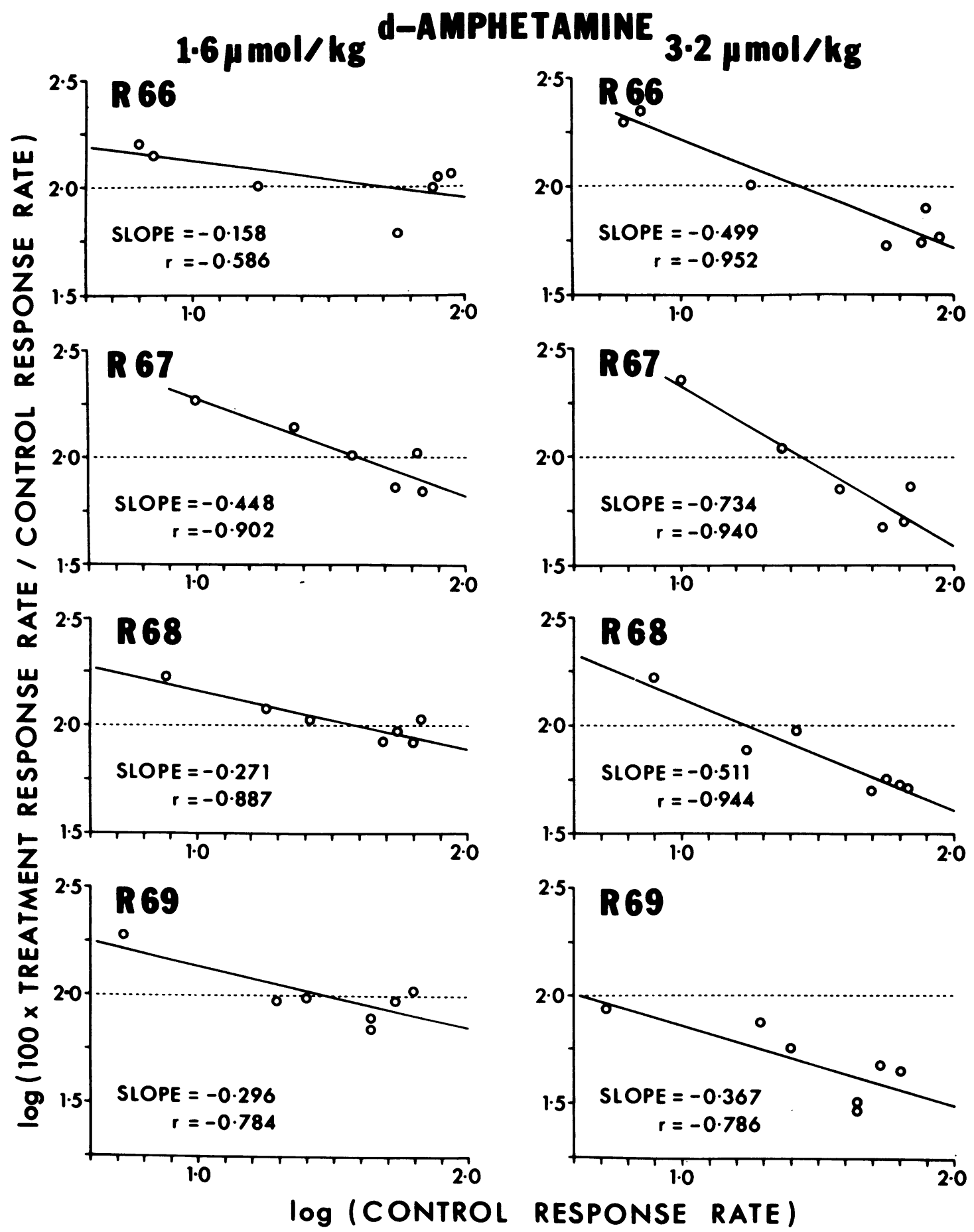

Fig. 3. Plots of response rates in the presence of $d$-amphetamine, expressed as percentage of response rates in control sessions, against response rates (responses per minute) in control sessions. Note double logarithmic coordinates. Horizontal broken lines indicate the ordinate value of $2.0(\log 100 \%)$; points above the line represent response rates which were enhanced in the presence of $d$-amphetamine, whereas points below the line represent rates which were suppressed in the presence of $d$-amphetamine. Continuous lines are regression lines fitted by method of least squares. In the case of each rat the line derived from the $3.2 \mu \mathrm{mol} / \mathrm{kg}$ data has a greater slope than that derived from the $1.6 \mu \mathrm{mol} / \mathrm{kg}$ data. 
Table 2), may reflect an interruption of operant responding by postprandial activities such as licking in the vicinity of the dipper aperture (cf. Iversen, 1978; Staddon, 1977); such an effect would have a more marked influence on response rates under the higher reinforcement frequency.)

The data displayed in Table 2 (see also Figure 1) indicate that $d$-amphetamine exerted different effects upon responding maintained by high and low reinforcement frequencies, the high response rates maintained by high reinforcement frequencies generally being suppressed, and the low response rates maintained by low reinforcement frequencies being either unaffected or elevated by the drug. These effects are reflected in the values of the two constants in Equation $1, R_{\max }$ and $K_{H}$, the values of both constants being reduced by the drug, at least in the case of the higher dose $(3.2 \mu \mathrm{mol} / \mathrm{kg})$. The values of the index of determination obtained from the sessions in which the drug was administered tended to be somewhat lower than those obtained from the control sessions. This may reflect the suppression of high response rates and elevation of low response rates by the drug; this would tend to reduce the total variance in the response rates and hence also the proportion of the variance accountable for in terms of reinforcement frequency. This tendency of $d$-amphetamine to reduce the variance in response rates was discussed by Gonzalez and Byrd (1977), who pointed out that as the dose of $d$-amphetamine is increased, so the rate of responding in the presence of the drug becomes more and more independent of the control response rate.

It has been suggested that variables which suppress responding in variable-interval schedules may be classified according to their effects upon $R_{\text {max }}$ and $K_{H}$ (Bradshaw et al., 1976; Bradshaw, Szabadi, \& Bevan, 1977; Bradshaw, Szabadi, \& Bevan, 1978a; Szabadi, Bradshaw, \& Ruddle, 1981). Such a classificatory scheme may be extended to include variables which facilitate or have mixed effects upon responding in these schedules. Altogether there are eight possible patterns of effects on the values of the two constants: three patterns of response suppression, three of response facilitation, and two of mixed effects. The three patterns of suppression are (i) a reduction in the value of $R_{\max }$, (ii) an increase in the value of $K_{H}$, and (iii) a combination of both these effects; variables have been identified which give rise to each of these three patterns (see Szabadi et al., 1981). The three patterns of facilitation are the mirror images of the three patterns of suppression: (iv) an increase in the value of $R_{\max }$, (v) a reduction in the value of $K_{H}$, and (vi) a combination of both these effects (for an example, see Bradshaw \& Szabadi, 1978). The two patterns of mixed effects are (vii) an increase in the value of $K_{H}$ coupled with an increase in the value of $\boldsymbol{R}_{\max }$ and (viii) the reverse of this. The effects of $d$-amphetamine seen in this experiment seem to correspond to type viii.

The differential effect of amphetamines upon responding occurring at high and low rates has been recognized for many years (Dews, 1958; for review see Dews \& DeWeese, 1977; Dews \& Wenger, 1977; Sanger \& Blackman, 1976). The rate-dependent effects of $d$ amphetamine seen in this experiment are illustrated in Figure 3, in which the data obtained from each rat are displayed in the conventional double-logarithmic plots of proportional change in response rate against control response rate. For each rat, lines of negative slope were obtained, the slope being steeper, and the value of the control response rate at which the drug had no effect being lower in the case of the higher dose than in the case of the lower dose. These findings based on terminal performance maintained under variable-interval schedules specifying a range of reinforcement frequencies are consistent with previous observations of the effects of amphetamines which have employed different procedures for manipulating response rate (see Dews \& DeWeese, 1977; Dews \& Wenger, 1977).

According to the rate-dependency hypothesis of the effect of amphetamines, it is the control rate of responding which is the crucial variable in determining the effect of these drugs (see Dews \& Wenger, 1977). A number of different procedures have been employed in order to generate the range of response rates needed to test this hypothesis; some studies compared performance maintained under qualitatively different schedules such as fixed-ratio and fixed-interval (Dews, 1958; Heffner, Drawbaugh, \& Zigmond, 1974), others compared the performance of animals which "spontaneously" exhibited high and low response rates under the same schedules (Ray \& Bivens, 1966; Will \& Checchinato, 1973), others compared 
local response rates during different segments of an extended fixed-interval (Branch \& Gollub, 1974; McMillan, 1969), and others examined performance maintained under a variable-interval schedule while manipulating a superimposed interresponse time procedure (McPhail \& Gollub, 1975) or pacing procedure (Sanger \& Blackman, 1975). No single study can be regarded as constituting a definitive proof of the rate-dependency hypothesis, since any procedure used to generate a range of response rates inevitably introduces other confounding factors (for example, different reinforcement frequencies, different reinforcement contingencies, or intersubject differences; see Branch \& Gollub, 1974; Sanger \& Blackman, 1975). In the present study, reinforcement frequency covaried with response rate; however, although the present experiment does not discriminate between the effects of control response rate and reinforcement frequency, it avoids the pitfalls associated with the use of local response rate (see Branch \& Gollub, 1974), response rates maintained by qualitatively different reinforcement schedules (see Sanger \& Blackman, 1975), and comparisons across different groups of subjects. The present results may therefore be regarded as complementary to previous findings in lending support to the rate-dependency hypothesis.

\section{REFERENCES}

Bradshaw, C. M. Suppression of response rates in variable-interval schedules by a concurrent schedule of reinforcement. British Journal of Psychology, 1977, 68, 473-480.

Bradshaw, C. M., \& Szabadi, E. Changes in operant behavior in a manic-depressive patient. Behavior Therapy, 1978, 9, 950-954.

Bradshaw, C. M., Szabadi, E., \& Bevan, P. Behavior of humans in variable-interval schedules of reinforcement. Journal of the Experimental Analysis of Behavior, 1976, 26, 135-141.

Bradshaw, C. M., Szabadi, E., \& Bevan, P. Effect of punishment on human variable-interval performance. Journal of the Experimental Analysis of Behavior, 1977, 27, 275-279.

Bradshaw, C. M., Szabadi, E., \& Bevan, P. Effect of variable-interval punishment on the behavior of humans in variable-interval schedules of monetary reinforcement. Journal of the Experimental Analysis of Behavior, 1978, 29, 161-166. (a)

Bradshaw, C. M., Szabadi, E., \& Bevan, P. Relationship between response rate and reinforcement frequency in variable-interval schedules: The effect of the concentration of sucrose reinforcement. Journal of the Experimental Analysis of Behavior, 1978, 29, 447452. (b)
Branch, M. N., \& Gollub, L. R. A detailed analysis of the effects of $d$-amphetamine on behavior under fixed-interval schedules. Journal of the Experimental Analysis of Behavior, 1974, 21, 519-539.

Catania, A. C., \& Reynolds, G. S. A quantitative analysis of the responding maintained by interval schedules of reinforcement. Journal of the Experimental Analysis of Behavior, 1968, 11, 327-383.

de Villiers, P. A. Choice in concurrent schedules and a quantitative formulation of the law of effect. In W. K. Honig \& J. E. R. Staddon (Eds.), Handbook of operant behavior. Englewood Cliffs, N.J.: PrenticeHall, 1977.

de Villiers, P. A., \& Herrnstein, R. J. Toward a law of response strength. Psychological Bulletin, 1976, 83, 1131-1153.

Dews, P. B. Studies on behavior, IV: Stimulant actions of methamphetamine. Journal of Pharmacology and Experimental Therapeutics, 1958, 122, 137-147.

Dews, P. B. A behavioral output enhancing effect of imipramine in pigeons. International Journal of Neuropharmacology, 1962, 1, 265-272.

Dews, P. B., \& DeWeese, J. Schedules of reinforcement. In L. L. Iversen, S. D. Iversen, \& S. H. Snyder (Eds.), Handbook of psychopharmacology (Vol. 7). New York: Plenum Press, 1977.

Dews, P. B., \& Wenger, G. R. Rate-dependency of the behavioural effects of amphetamine. In $T$. Thompson \& P. B. Dews (Eds.), Advances in behavioral pharmacology (Vol. 1). New York: Academic Press, 1977.

Ferster, C. B., \& Skinner, B. F. Schedules of reinforcement. New York: Appleton-Century-Crofts, 1957.

Gonzalez, F. A., \& Byrd, L. D. Mathematics underlying the rate-dependency hypothesis. Science, 1977, 195, 546-550.

Heffner, T. G., Drawbaugh, R. B., \& Zigmond, M. J. Amphetamine and operant behavior in rats: Relationship between drug effect and control response rate. Journal of Comparative and Physiological Psychology, 1974, 86, 1031-1043.

Herrnstein, R. J. On the law of effect. Journal of the Experimental Analysis of Behavior, 1970, 13, 243-266.

Herrnstein, R. J. Formal properties of the matching law. Journal of the Experimental Analysis of Behavior, 1974, 21, 159-164.

Iversen, I. H. Collateral responses with simple schedules. In W. W. Henton \& I. H. Iversen, Classical conditioning and operant conditioning. New York: Springer-Verlag, 1978.

Lewis, D. Quantitative methods in psychology. New York: McGraw-Hill, 1960.

McMillan, D. E. Effects of $d$-amphetamine on performance under several parameters of multiple fixedratio, fixed-interval schedules. Journal of Pharmacology and Experimental Therapeutics, 1969, 167, 26-33.

McPhail, R. C., \& Gollub, L. R. Separating the effects of response rate and reinforcement frequency in the rate-dependent effects of amphetamine and scopolamine on the schedule-controlled performance of rats and pigeons. Journal of Pharmacology and Experimental Therapeutics, 1975, 194, 332-342.

Ray, O. S., \& Bivens, L. W. Chlorpromazine and amphetamine effects on three operant and four discrete 
trial reinforcement schedules. Psychopharmacologia, $1966,10,32-43$.

Sanger, D. J., \& Blackman, D. E. Rate-dependent effects of drugs on the variable-interval behavior of rats. Journal of Pharmacology and Experimental Thera. peutics, 1975, 194, 343-350.

Sanger, D. J., \& Blackman, D. E. Rate-dependent effects of drugs: A review of the literature. Pharmacology, Biochemistry and Behavior, 1976, 4, 73-83.

Staddon, J. E. R. Schedule-induced behavior. In W. K. Honig \& J. E. R. Staddon (Eds.), Handbook of operant behavior. Englewood Cliffs, N.J.: Prentice-Hall, 1977.

Szabadi, E., Bradshaw, C. M., \& Ruddle, H. V. Rein- forcement processes in affective illness: Towards a quantitative analysis. In C. M. Bradshaw, E. Szabadi, \& C. F. Lowe (Eds.), Quantification of steady-state operant behaviour. Amsterdam: Elsevier/North Holland Biomedical Press, 1981.

Wilkinson, G. N. Statistical estimations in enzyme kinetics. Biochemical Journal, 1961, 80, 324-332.

Will, B., \& Checchinato, D. Effects of $d$-amphetamine on operant behaviour in the rat. Psychopharmacologia, 1973, 29, 141-149.

Received February 11, 1980

Final acceptance January 31, 1981 